\title{
Ethnocentric behavior of consumers on the market of food products in Poland
}

\author{
Robert Jadach \\ Wrocław University of Economics, School of Management, Computer Science and Finance, Komandorska 118-120, Wrocław, \\ Poland \\ Corresponding author: robertjadach933@gmail.com \\ DOI: $10.31708 /$ spi3.18/jada.cns18
}

\section{Introduction}

The concept of consumer ethnocentrism was defined for the first time by two American scientists T.A. Shimpa and $S$. Sharma and it mainly concerned decisions related to the selection, purchase and use by buyers of domestic products (Shimp \& Sharma, 1987). This behavior was described as the "overestimation" of products of native origin, a reduction in the value of imported products and the abandonment of their purchase. This behavior is also identified with the preference for both domestic products as well as regional and local products (Sharma, Shimp, 1987, p. 280-289). The problems of ethnocentric behavior in Poland were only interested after the fall of communism in 1898, when consumers, as a result of marketization of the economy, gained the freedom to choose products and services according to their individual preferences (Kowalczyk, 2016). Research in this period showed that the ethnocentric attitude among Polish buyers was low. Consumers then preferred foreign products, which was a consequence of a lack of confidence in goods produced in the country, which were perceived as weaker in quality compared to imported products. Over time, the ethnocentric orientation grew stronger, especially in the context of agri-food goods (Figiel, 2004). The aim of the article is to assess the level of ethnocentric shopping behavior in the context of buying food products among Polish consumers (Angowski \& Lipowski, 2014; Szromnik \& Wolanin-Jarosz, 2014).

\section{Materials and Methods}

In order to check the level of consumer ethnocentrism, a survey was conducted among Polish consumers. The research method was a specially prepared online questionnaire, containing questions about the issue of consumer behavior in the context of purchasing food products. The selection of the participants of the online survey was random, covering Polish consumers in all ages. The questionnaire consisted of two parts. The first part contained questions about the shopping behavior of Polish consumers of food products. In the first part of the questionnaire respondents were asked to indicate the brand they would choose more willingly during shopping (from a pair of food brands). The second part contained questions allowing the general character of the respondents due to income, place of confusion, age and gender. The source of secondary information was the CBOS marketing research agency.

\section{Results}

In the category of fruit juices, consumers have declared that during shopping they would prefer Tymbark (Polish brand) $-87,3 \%$, while the foreign brand Cappy would choose $12.7 \%$ of the respondents. In the case of yoghurts, with the choice of the Polish Bakoma brand and the foreign Donone, most consumers (57.3\%) would choose Donone. The foreign brand would also be chosen by the buyer in the case of ice cream desserts: Algida (foreign brand) - 56.4\%, Koral (Polish brand) - 43.6\%.
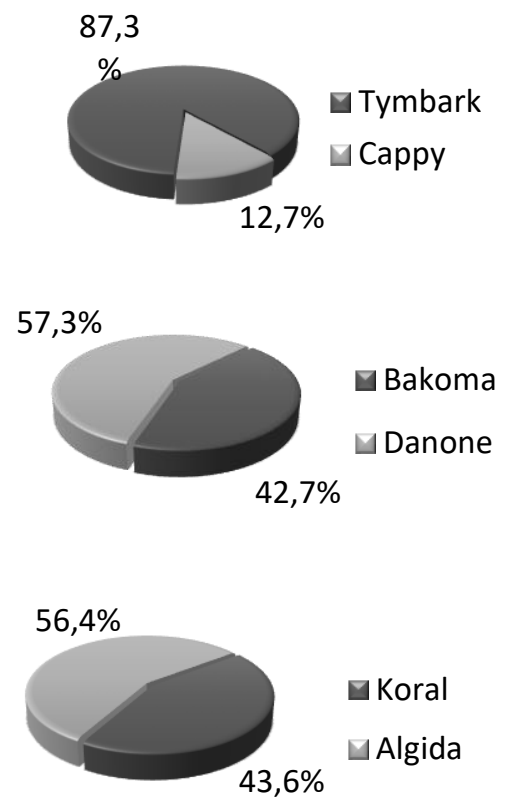

Fig. 1, 2, 3. Answer the question: Please, specify the brand you would like to buy during shopping? Source: Author's study. 


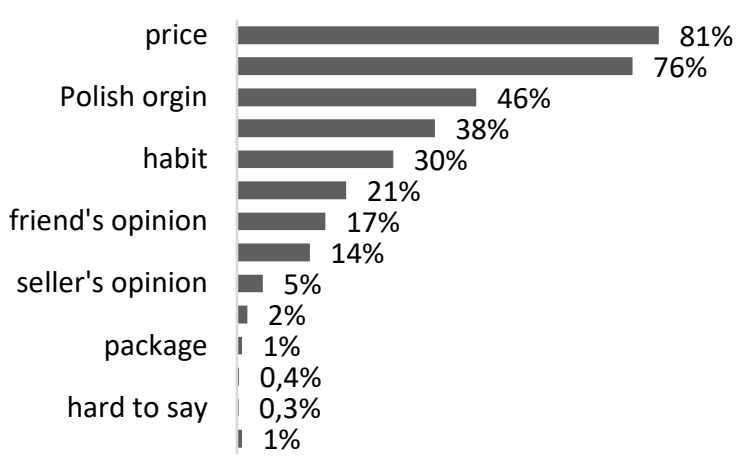

Fig. 4. Answer the question: What do you pay attention to when buying a daily use product? Source: CBOS.

The most important criteria for consumers when buying products for everyday use is price (81\%) and quality (76\%). The Polish origin of the product ranks third in this respect - almost half of Poles (46\%) indicate it (Centrum Badania Opinii Społecznej, 2017).

\section{Discussion}

The conducted research allowed to assess the ethnocentric behavior of buyers in the context of purchasing food products. Analyzing respondents' answers it can be concluded that the level of consumer ethnocentrism in the case of purchasing food products is noticeable. The Polish origin of the product ranks third in consumer purchasing factors - almost half of Poles (46\%) indicate it (Centrum Badania Opinii Społecznej, 2017). This is very important information, because even in the $80 \mathrm{~s}$ and 90 s of the last century, consumer ethnocentrism among Polish consumers was at a low level (Angowski \& Lipowski, 2014). Generally, it can be concluded that buyers prefer Polish brands, especially in the fruit juice category, foreign brands in the case of ice cream desserts and yogurts.

\section{References}

Angowski, M., \& Lipowski, M. (2014). Uwarunkowania wyboru produktów żywnościowych i miejsc ich zakupu. Marketing i Rynek, 2014(6), 2-16.

Retrieved from http://www.pwe.com.pl/files/1676169416/file/spis_t resci_streszczenia_cd_6.pdf

Centrum Badania Opinii Społecznej. (2017). Patriotyzm gospodarczy.

Figiel, A. (2004). Etnocetryzm [i.e. etnocentryzm] konsumencki : produkty krajowe czy zagraniczne (I). Polskie Wydawn. Ekonomiczne. Retrieved from https://eki.pl/index.php?br1=30000\&br2=31400\&d etailed=PWE535\&

Kowalczyk, E. (2016). Współczesne Problemy Ekonomiczne. Globalizacja, Liberalizacja, Etyka. Współczesne Problemy Ekonomiczne. Globalizacja. Liberalizacja. Etyka. Wydawnictwo
Naukowe Uniwersytetu Szczecińskiego. Retrieved from https://www.ceeol.com/search/articledetail id $=558816$

Shimp, T. A., \& Sharma, S. (1987). Consumer Ethnocentrism: Construction and Validation of the CETSCALE. Journal of Marketing Research, 24(3), 280. https://doi.org/10.2307/3151638

Szromnik, A., \& Wolanin-Jarosz, E. (2014). Etnocentryzm konsumencki na zglobalizowanym rynku-czynniki i procesy kształtowania (cz. 1). Marketing i Rynek, 4(21), 2-14. Retrieved from http://www.marketingirynek.pl/files/1276809751/fil e/mir_04_2014_szromnik.pdf 